\title{
Test Excavation at Site 41KT32 Kent County, Texas
}

Joe T. Denton

Follow this and additional works at: https://scholarworks.sfasu.edu/ita

Part of the American Material Culture Commons, Archaeological Anthropology Commons, Environmental Studies Commons, Other American Studies Commons, Other Arts and Humanities Commons, Other History of Art, Architecture, and Archaeology Commons, and the United States History Commons

Tell us how this article helped you.

This Article is brought to you for free and open access by the Center for Regional Heritage Research at SFA ScholarWorks. It has been accepted for inclusion in Index of Texas Archaeology: Open Access Gray Literature from the Lone Star State by an authorized editor of SFA ScholarWorks. For more information, please contact cdsscholarworks@sfasu.edu. 


\section{Test Excavation at Site 41KT32 Kent County, Texas}

\section{Licensing Statement}

This is a work produced for the Texas Department of Transportation (TxDOT) by the report producer. TxDOT and the report producer jointly own all rights, title, and interest in and to all intellectual property developed under TXDOT's contract with the report producer. The report may be cited and brief passages from this publication may be reproduced without permission provided that credit is given to both TxDOT and the report producer. Permission to reprint an entire chapter, section, figures or tables must be obtained in advance from either the Supervisor of the Archeological Studies Branch, Environmental Affairs Division, Texas Department of Transportation, 125 East 11th Street, Austin, Texas, 78701 or from the report producer. 


\section{TEST EXCAVATIONS AT SITE 41KT32}

KENT COUNTY, TEXAS

By

Joe T. Denton

Texas

State Department of Highways and Public Transportation

Highway Design Division

November 1983 


\section{ABSTRACT}

Site $41 K T 32$ is an open prehistoric campsite located on the Salt Fork of the Brazos River in Kent County, Texas. Test excavations revealed that the site is primarily outside of the proposed bridge replacement project area. Scattered burned rock was noted, and artifacts recovered indicate site habitation during the Late Archaic Period.

On the basis of the site's limited extent within the project and the lack of direct impact by the project on the primary portion of the site, no further investigation is being recommended. 


\section{INTRODUCTION}

Archaeological Site 41KT32 was reported in September, 1983, by a member of the State Department of Highways and Public Transportation (SDHPT) Archaeology Section, with the recommendation for testing. Testing was conducted by the author, members of the local maintenance office in Jayton, and members of the district lab personnel in Abilene. Excavations were conducted during the period of November 1 through November 3 , 1983, in accordance with Procedures for the Protection of Historic and Cultural Properties (36 CFR, Part 800), procedures which are prescribed and endorsed by the Federal Highway Administration. Test objectives were to determine eligibility to the National Register of Historic Places and to determine the nature and cultural context of the deposits.

The site, 41KT32, is located above the floodplain on the south terrace of the Salt Fork of the Brazos River, adjacent to and west of State Highway 208 (Fig. 1). The confluence of Gap Creek and the Salt Fork is approximately $200 \mathrm{ft}$. downstream from the site and east of State Highway 208. 
This Page Redacted Per THC Policy 


\section{SITE AND PROJECT DESCRIPTION}

The site, 41KT32, had previously been disturbed by the construction of State Highway 208 which now represents the eastern limit of the site. Cultural material exposed by the highway is evident in the right-of-way along the cut slope on the west side of the highway. Additional limits of the site are based on surface reconnaissance beyond the extent of the highway right-of-way. Cultural material is evident in erosional gullies and rills approximately $400 \mathrm{ft}$. to the west and approximately $300 \mathrm{ft}$. along the project right-of-way (Fig. 2). Evidence is also present downslope toward the Salt Fork since much of the lower portion of the site has been subjected to sheetwash thus displacing cultural material. Flooding from the river also has been frequent on the lower portion of the terrace.

The proposed project consists of the removal of the existing bridge structure with construction of a new structure at the same location within the existing right-of-way. During the construction, a temporary easement and detour will be required and will have a maximum width of $100 \mathrm{ft}$. This temporary easement will be upstream to the present bridge. After completion of the project the easement will revert to the landowner. A channel easement is presently being maintained on the downstream side of the project. Detour construction will be limited to a $20 \mathrm{ft}$. wide asphalt surface over flexible base roadway with a minimum of earth movement. Only the upstream easement will have a direct impact on the archaeological site (Fig. 2). More than $95 \%$ of the site is outside the right-of-way and will not be involved in the project area. 


\section{SOILS}

The soils in the area consist of the Quinlanseries and Woodward and Quinlan series. These soils formed from Permian age materials of soft, fine-grained sandstones, pack sands, silty shales, and gypsum.

The principal soil at the site is the Woodward and Quinlan series sandy loam. This soil is found on the side slopes of ridges and knolls. The soil is typified by yellowish red, very fine sandy loam over reddish yellow very sandy loam to a depth of $14 \mathrm{in}$. Underlying is a yellowish red very fine sandy loam with gray flakes of gypsum precipitates. The soils are highly susceptible to wind and water erosion (Richardson and Girdner 1973). Soils encountered during testing generally reflect those described for the Woodward and Quinlan series except for a noticeable increase in organics and color differences. The soils are soft and animal disturbances are very numerous and active. 
PROCEDURES

Testing consisted of hand-excavated units and profiles, including four 1 by 2 meter units, one 1 by 1 meter unit, and a profile of the cut bank exposed on the west right-of-way. Excavation was conducted by shovel and trowel, and all soil was screened through 1/4 in. hardware cloth. All cultural material was bagged and labeled according to provenience. Artifacts and burned rocks were recorded in situ when encountered. Excavation was in $10 \mathrm{~cm}$ levels and was continued to bedrock or was halted when sterile deposits were encountered.

Test Units 1, 2, and 5 were concentrated in the area of highest cultural evidence while Test Units 3 and 4 were in areas downslope (Fig. 3). A surface collection was made from the entire site. 


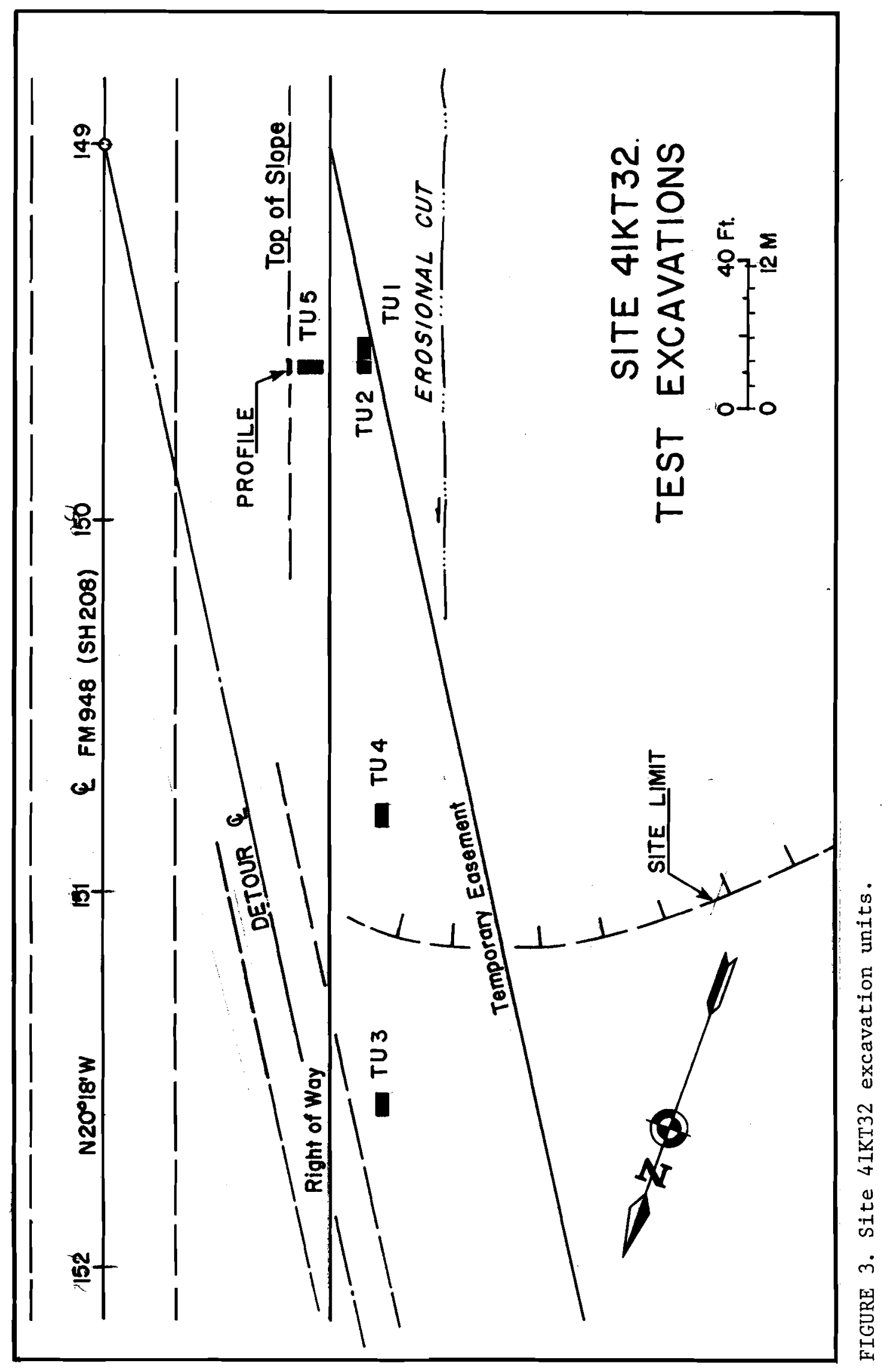


FEATURES

Excavations in Test Units 1, 2, and 5, revealed a deposit containing widely scattered burned sandstone. The burned stones were small to large cobble size with fracturing, discoloration, and thermal altering evident. No distinct patterns or features were recognized (Fig. 4).

The scatter of burned rock was contained within Levels 2 and 3 or 10 to $30 \mathrm{~cm}$ below the present ground surface. This layer of debris occupied approximately the lower half of Zone $\mathbf{1}$, the medium dark tan, very fine sandy loam (Fig. 4). Heavy rodent activity was noted in this zone. Zone 2, a medium tan sand, had very 1 ittle cultural evidence, and Zone 3, a gypsum-red sand, was sterile.

A surface erosional area to the west of Test Units 1, 2, and 5 and outside the project area, also contained scattered burned rock and cultural evidence. No isolated features were evident in either the test units or the areas exposed by erosion. 


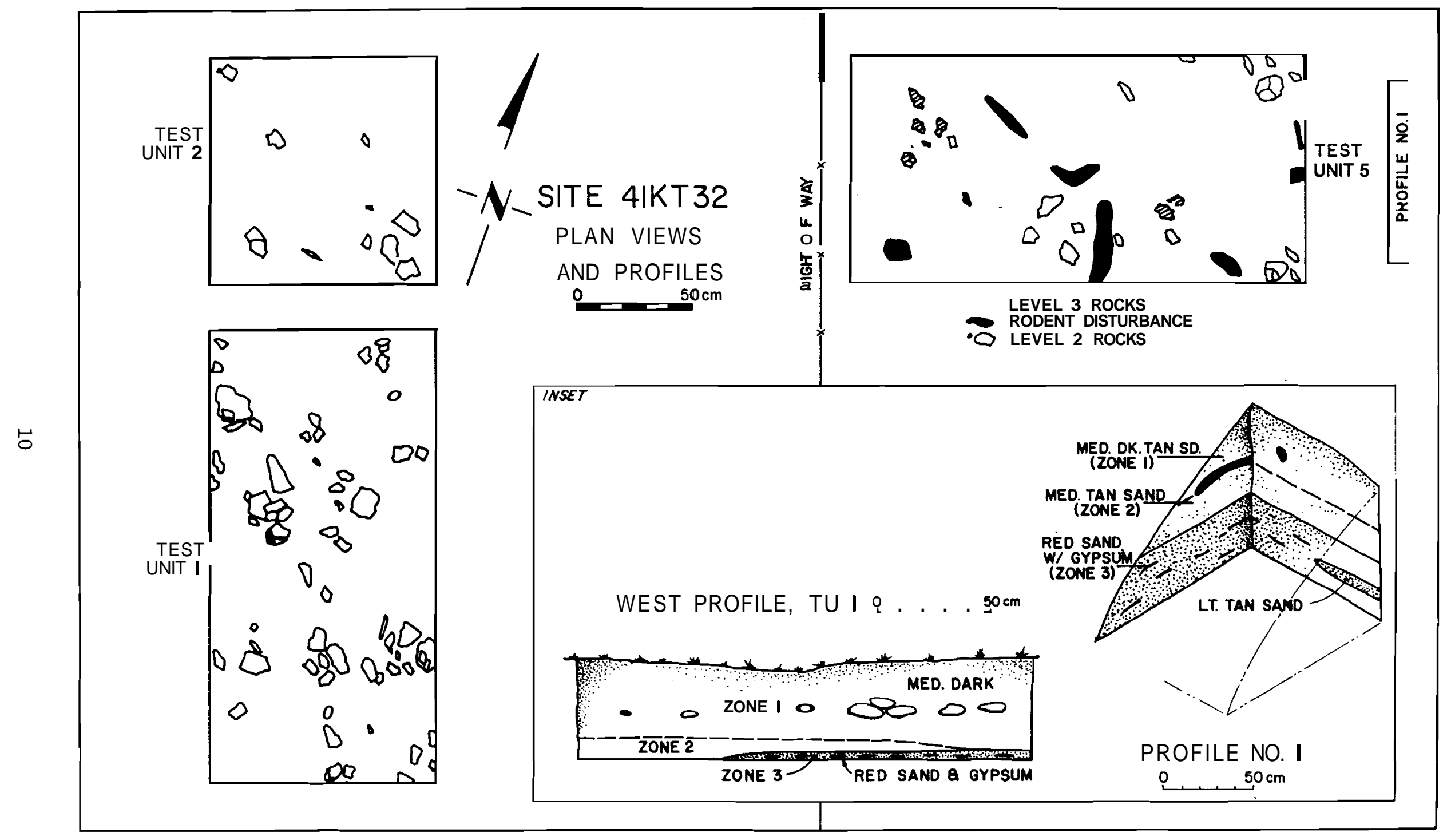

FIGURE 4. Profiles and plan views of test excavations at $41 \mathrm{KT} 32$. 


\section{ARTIFACTS}

A total of 37 artifacts, including surface finds, was recovered during the test excavations. An additional 696 flakes were also recovered. Artifacts recovered include projectile point fragments, biface fragments, uniface fragments, modified flakes, cores, choppers, and ground stone.

\section{PROJECTILE POINT FRAGMENTS}

Two dart point stem fragments were recovered, both of which are similar with expanding and slightly convex bases. Both appear to be from small dart points. One specimen (Fig. 5A) is of red Alibates flint and the other (Fig. 5B) is of a translucent mottled tan flint. Due to the degree of fragmentation, the only measurement taken was base width. Both bases are $1.7 \mathrm{~cm}$ wide. Provenience: A, Test Unit 2, Level 4; B, Test Unit 1, Level 2.

Two projectile point medial fragments were recovered, one of which is complete enough to show artifact form. This fragment (Fig. 5C) is lacking the distal tip, one lateral edge, and the base. Fracturing appears to have been from impact. The fragment indicates that the projectile point was bifaced with weak shoulders. Stem shape is undetermined. Thickness is $6 \mathrm{~mm}$. Material is a creamy white chert. The other specimen is of light gray Edwards chert. Provenience: Test Unit 1, Level 2; and Test Unit 2, Level 4.

Three projectile point distal fragments were recovered from Test Unit 5, Levels 2, 3, and 6. Two exhibit impact fractures on the tips and snap fractures from the main blade. Material utilized for manufacture is a waxy, tan chert. 


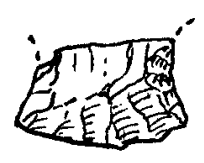

A

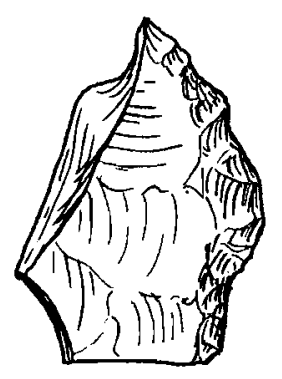

C

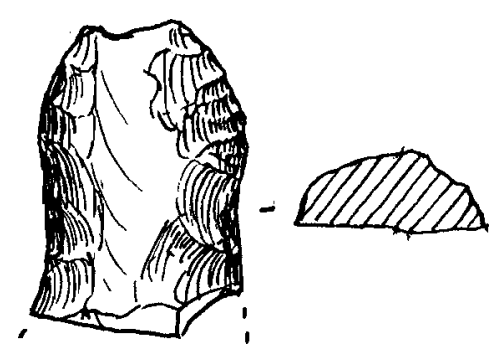

E

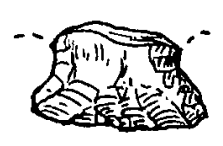

B
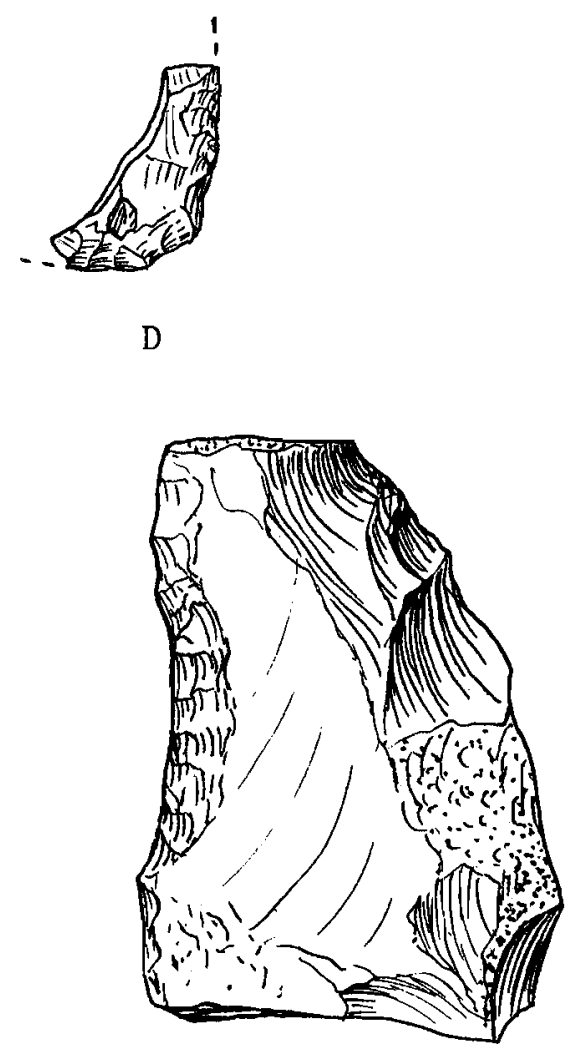

$\mathrm{F}$

FIGURE 5. Artifacts recovered in test excavations at 41KT32. A,B, dart point stems; C, dart point fragment; D, small biface fragment; and $E, F$, unifaces. 


\section{MISCELANEOUS BIFACE RAGMENIS}

A small, thinned biface lateral fragment was recovered from Test Unit 5, Level 4, and possibly represents a projectile point preform. The specimen (Fig. 5D) is somewhat subrectangular in shape and exhibits ground edges with no retouch. Overall size of the fragment indicates the possibility that the fragment may be a preform for a small projectile point.

The only large biface fragment recovered during the test was a fragment of a possible knife. This specimen, a surface find, has a rounded tip with a bevel on one lateral edge. The beveled edge is sharp and the unbeveled edge is dulled from either intentional grinding or use. Flake scars on one blade surface are smoothed presumably from natural sandblasting.

Two additional small lateral biface edge fragments were recovered, one from Test Unit 3, Level 2, and one from Test Unit 5, Level 3. Both exhibit secondary and tertiary flaking.

\section{UNIFACES}

Three uniface fragments were recovered. One (Fig. 5E) is of a gray flint similar to Edwards flint. This specimen is narrow and thick and exhibits steep beveling on both lateral edges on the dorsal surface. Two additional unifaces exhibit beveling on one lateral edge (Fig. 5F). Beveled edges on one specimen are somewhat smoothed but do not exhibit polish. Material of the latter specimen is a coarse-grained Ogalalla quartzite and tan to pink in color. Provenience: Surface; Test Unit 1, Level 12; Test Unit 4, Level 4.

\section{MODIFIED FLAKES}

Five flakes were recovered which exhibit some edge nibbling. Two were surface finds and the remainder are from Test Unit 1, Level 2; Test Unit 2, Level 1; and Test Unit 5, Level 3. Modification consists of slight beveling on small sections of the flake edges. 


\section{CORES}

Five cores were recovered from test excavations and an additional core was recovered from the surface collection. The material utilized consists of 3 coarse-grained cherts light tan to tan in color, 1 dark tan fine-grained petrified wood, and 1 large piece of Alibates flint. The Alibates specimen was a surface find with the remainder from Test Unit 1, Levels 1, 2, and 3, and Test Unit 3, Level 5.

\section{HAMMERSTONES}

Four hammerstones were recovered. All are quartzite cobbles and exhibit pronounced pecking and/or battering on the ends. One specimen, a surface find, is a black quartzite; and length is $98 \mathrm{~mm}$, width is $80 \mathrm{~mm}$, and thickness $45 \mathrm{~mm}$. A smaller specimen of reddish brown quartzite exhibits flake removal and some battering along one edge of the cobble. The length is $55 \mathrm{~mm}$, width is $50 \mathrm{~mm}$, and thickness is $20 \mathrm{~mm}$. Provenience: Surface; Test Unit 2, Levels 1 and 2; and Test Unit 4, Level 3.

MANOS

A total of 4 specimens was recovered during the test. Two types of manos are represented and two of each type were found. The first type is a small, palm-sized quartzite cobble with at least one smoothed surface. Both specimens of this type are symmetrical and double convex in cross-section. Both are from Test Unit 5, Levels 3 and 4. The second type of mano is larger and is rectangularly shaped. One specimen, a fragment, was recovered from Test Unit 4, Level 1. It has two flat surfaces. The other is complete and was a surface find from the western extent of the site. It has one slightly rounded surface and one well rounded surface. Both surfaces exhibit striations perpendicular to the long axis of the mano. The length is $12.3 \mathrm{~cm}$, width is $75 \mathrm{~mm}$, and thickness is $47 \mathrm{~mm}$. 
GRINDING STONE

This single specimen was located in Test Unit 1, Level 3 . It is a fragment, approximately one-fourth of the whole, with a dished surface on each face. The material is a calcareous sandstone. The fragment is $15.0 \mathrm{~cm}$ long, $10 \mathrm{~cm}$ wide, with a maximum thickness of $38 \mathrm{~mm}$ on the outside edge and $22 \mathrm{~mm}$ minimum thickness.

SANDSTONE PESTLE?

This sandstone object has been tentatively classified as a possible pestle although the specimen is fragmented. It is smoothed but not polished or ground. Shape is biconvex in cross-section and squared at one end. The overall shape is cylindrical, and the specimen is $10 \mathrm{~cm}$ in length, $40 \mathrm{~mm}$ wide, and $22 \mathrm{~mm}$ thick. Provenience: Test Unit 5, Level 3.

MISCELLANEOUS QUARTZITE

Three quartzite fragments were recovered with smooth surfaces but no evidence of polish. While each is fragmented they are tentatively designated as mano fragments. Material is a reddish tan to reddish brown quartzite. Provenience: Test Unit 1, Levels 1 and 3; Test Unit 5, Level 4.

DEBITAGE

A total of 696 flakes and chips were recovered with the majority recovered from Test Units 1, 2, and 5. Five flakes of Alibates flint were recovered in the test units and three from the surface. 
ARTIFACT ANALYSIS AND DISTRIBUTION

Surface collection, which included areas outside the project limits, produced a total of 7 artifacts including 1 biface fragment, 1 uniface, 2 modified flakes, 1 core, 1 battered cobble, and 1 mano.

Excavation produced a total of 30 artifacts. Of the artifacts $98 \%$ were concentrated in Test Units 1, 2, and 5; and 92\% of the flakes and debitage were also concentrated in these same units. Only $2 \%$ of the artifacts recovered were from Test Units 3 and 4 as well as only 8\% of the debitage.

Vertical distribution of artifacts is concentrated in Levels 1 through 4, with highest density in Levels 2 and 3 . Only 6\% of the artifacts were recovered below Level $4(40 \mathrm{~cm})$. Sixty percent of the artifacts recovered were in Levels 2 and $3(10$ to $30 \mathrm{~cm})$. This narrow zone of artifact concentration corresponds to the level of burned rock scatter. The projectile point fragments in the inventory appear to be Late Archaic and would suggest some hunting subsistence. The manos and grinding stone demonstrate vegetal harvesting and processing as well.

The lithics at the site demonstrate a wide occurence. While most are local in origin at least two examples of Edwards flint, seven examples of Alibates flint, and two examples of Ogalalla quartzite were found. This variety would indicate at least some contact with the Edwards Plateau region and the Lower Plains area of the Texas Panhandle. Ogalalla quartzite is also known in East Texas as Potter chert. If these specimens are from that area, then this occurrence would also indicate a contact to the east. 
Site 41 KT32 is a prehistoric aboriginal campsite located principally outside of the SDHPT project. The area of maximum artifact recovery within the project is limited to a very small knoll at the edge of the detour easement. The maximum area available for testing within the present right-of-way represents approximately 75 square meters, $7 \%$ of which has been excavated. The remainder according to project designs is not in immediate danger of destruction.

Based on recovered materials the site is believed to be a short-term single component campsite. While intact features were not encountered, it is probable that features are present within the site. The presence of ground stone artifacts, tool manufacturing artifacts, as well as projectile point fragments indicates that all food and 1 ithic resources were being utilized. The presence of Alibates flint, Edwards flint, and Ogalalla quartzite also indicates that distant resources were known and exploited either directly or indirectly by trade.

Based on the limited area to be affected, rodent disturbances, percentage of site already tested, and project design, it is believed that the portion of the site under state control requires no further investigation and does not meet the criteria for inclusion within the National Register of Historic Places. 
REFERENCES CITED

Richardson, W.E., and C.I. Girdner

1973 Soil Survey of Kent County, Texas. United States Department of Agriculture Soil Conservation Service. 